\title{
VOCAȚIA MISIUNII ŞI MISIUNEA SLUJIRII BISERICII ÎN POSTMODERNISM
}

\author{
Marius Sorin Radomir*
}

\begin{abstract}
The society we live in moves and becomes dynamic in a world more and more lamentable, subject inevitably to that modern "speed demon", forgetting "with premonition" it's true classical values and departing from the mystical Jesus body, from the Church.

One can notice a programmed and vehement upset of the values of the authentic Christianity, a spiritual suicide promoted and stirred particularly by some circles outside the spiritual life and the Church's spirit.

Today, one can also notice, a spiritual struggle with the spirit of this world that became blind by sin, sank into a more and more profound spiritual crisis, into a continuous war with its own identity which nobody will take advantage of, and thus, the spiritual disaster and not only, can become immeasurable at a given moment.

Following its own purpose of salvation, not only that it gives to man the divine life, but it also spreads, in a way, over the entire world, the light of this life, especially by healing and raising the human person's dignity, consolidating the social cohesion and rendering, to the daily activity, a sense and a more profound significance. The Church involvement becomes fundamental at the familial, social and historic levels, thus, having a certain mission given by Jesus through the Holy Apostles, toward all of us, the actual people, as legitimate descendants of its spiritual thesaurus.
\end{abstract}

Keywords: Christ, Church, God, religions, divinity, Messiah, mosaic law, Holy Spirit, Apostles, Day of Pentecost, Trinity Union, mission of the Church, Tradition and the Life of the Church, missionary activity, Gospel.

Societatea în care trăim se mişcă şi se dinaminează într-o lume din ce în ce mai lamentabilă, supusă inevitabil acelui "speed demon"

\footnotetext{
* Deacon, Phd. Assistant, University of Piteşti (The Faculty of Orthodox Theology "Sfânta Muceniță Filoteia")
} 
modern, uitând $\mathrm{cu}$,premoniție” adevăratele sale valori clasice şi depărtându-se de trupul mistic al lui Hristos Dumnezeu, de Biserică.

Asistăm la o răsturnare programată şi vehementă a valorilor creştinismului autentic, la un suicid spiritual promovat şi provocat în special de cercuri exterioare vieții duhovniceşti şi spiritului Bisericii. Asistăm astăzi la confruntarea duhovnicească cu spiritul acestei lumi orbite de păcat, afundându-se într-o criză spirituală din ce în ce mai profundă, într-un perpetuum război cu propria identitate din care nimeni nu va avea de câştigat iar dezastrul spiritual, şi nu numai, poate deveni incomensurabil la un moment dat.

Într-o astfel de atmosferă vieţuieşte astăzi Biserica şi mădularele ei vii, credincioşii şi clerul, căci cu toții Îl slujim pe Unul şi Prea Bunul Dumnezeu, cu binecuvântarea Tatălui, cu puterea şi lucrarea Sfântului Duh, în Iisus Hristos Domnul nostru, cu speranța psalmistului care zice: ,Scoate-mă, Doamne, de la omul viclean şi de omul nedrept mă izbăveşte[...]. Ştiu că Domnul va face judecată celui sărac şi dreptate celor sărmani; iar drepții vor lăuda numele Tău şi vor locui cei drepți în fața Ta!'( Psalmul 139, 1,12-13).

Misiunea Bisericii ca vocație şi slujire presupune deopotrivă hristocentrismul dublat de accentul pus pe teandria exemplificată de raportul celor două firi în Persoana lui Mesia, importanța harului divin necreat de la creație până la hristificare, rolul Bisericii ca trup mistic al lui Hristos şi panteon în viața cetății societății moderne, panbisericismul şi viziunea ecumenică a creştinismului, pancosmismul, neo-ortodoxismul, teologia mistică şi teologia estetică. Opera teologică şi mistică a Bisericii devine astfel o hermeneutică pentru vocația misiunii şi misiunea slujirii sale cu puternice implicații la nivelul teologiei contemporane şi al societății postmoderne.

Urmând unei critici flămânde de adevăr, acum când istoria scoate la lumină elemente de senzație capabile să răstoarne valorile prezente considerate imuabile, este timpul să despărțim grâul de neghină, clasicul de profan, profetismul de metodă, unind rațiunea şi inima într-un cuget, acela creştin, pe care misiunea Bisericii îl promovează cu ardoare de la viață până la moarte şi încă moartea lui 
Hristos pe crucea dătătoare de viață pentru adevăr, pentru libertate şi cuvânt. Misiunea Bisericii ca vocaţie şi slujire devine una evanghelică, teologică şi mistică deopotrivă, cu mici nuanțe contextuale, însă cu un țel comun: preamărirea lui Dumnezeu şi îndumnezeirea omului prin harul divin necreat.

Într-o evocare de o simplitate genială, mărturisim crezul ortodox de nezdruncinat, prin exemplul preoției sacramentale ca instrument al misiunii, dar şi prin metafora evocării Sfântului Ioan Botezătorul, Înaintemergătorul, din al cărui exemplu Biserica mărturiseşte cu aceeaşi ardoare, precum glasul celui ce strigă în pustie: „, Glasul celui ce strigă în pustie: Pregătiți calea Domnului, drepte faceți cărările Lui'(Matei 3, 3).

Dacă ar fi să divagăm misiunea Bisericii cu exemplul românesc, atunci putem afirma cu tărie că ortodoxia românească este un filon de cultură tradițională, dar şi modernă, mereu proaspătă, plină de spiritualitate şi teologie ortodoxă, învăluită în mistica „Bisericii celei una (koinonia)", Din întreaga misiune a Bisericii răzbate chemarea Cuvântului, care s-a făcut trup (Ioan 1,14) şi S-a sălăşluit între (întru) noi, uneori chiar sub influența Ideii lui Platon, importanța religiei în ființa omului ca homo religiosus ${ }^{2}$, forța spirituală şi valorile inestimabile ale tainelor creştinătăţii, originalitatea învățăturii dogmatice ce emană din conținutul Sfintei Scripturi şi Scrierile Sfinților Părinți ai Bisericii celei una, confluența dintre spațiu, timp şi etnic în cultura şi ființa unui popor, formula analogică a tradiționalismului, corespondența dintre spirit şi materie,

${ }^{1}$ cf. "The Unity of the Church as Koinonia: Gift and Calling" (Unitatea Bisericii drept Koinonia: Dar şi Chemare), declarația de la Camberra, 2,1.

2 Mircea Eliade, Sacrul şi profanul, traducere din limba franceză de Brânduşa Prelipceanu, ediţia a III-a, Bucureşti, Editura Humanitas, 2005, p. 122. 
transfigurarea mitului creator, legi scrise şi nescrise, care devin căminul cultural $^{3}$ al unui popor sau cartea sa de căpătâi.

Originalitatea şi complexitatea misiunii Bisericii ca vocaţie şi slujire radiază de energie holistică, învăluită de misterul creştin al Întrupării şi dinamica trimiterii la propovăduire, dar cu o autoritate ce nu poate contestată, aceasta fiind însăşi succesiunea apostolică pe care Biserica contemporană trebuie să o promoveze cu toată opoziția a ceea ce putem numi prin extrapolare barbaria secolului $X X^{4}$, referindu-ne la atitudinea lumii postmoderne identică în manifestare cu epoca de aur a comunismului.

Aceeaşi autoritate vocațională a misiunii, prin slujirea care face mulțimile să renască, dar lasă intelectualitatea la distanța de siguranță, promovează Biserica plină de virtuți, o Biserică smerită, chiar modestă, dar şi complexă, simplă, dar şi academică, statornică, dar şi speculativă, calmă, dar şi vulcanică, spirituală, dar şi contradictorie şi cu siguranţă prea puțin înțeleasă.

Biserica, prin misiunea sa, este o personalitate teandrică care, dincolo de vitregiile epocii în care trăim, intuieşte, după o îndelungată studiere a cuvântului Scripturii, a scrierilor Sfinților Părinți ai Bisericii, o transpunere firească şi accesibilă a unor termeni cu o complexitate aparte, reuşind acest lucru tocmai prin prisma cunoştințelor tezaurului ei inestimabil, conjugate de teologie, filosofie şi tradiționalism. Biserica reunifică astfel crezul patristic, cu exemplificările teologiei, cu mistica dionisiană, cu tradițiile încreştinate ale popoarelor, umplând de spirit întreaga materie, unificând spațiul şi timpul sacru în forma coerentă a limbajului

${ }^{3}$ Gh. D. Mugur, Nichifor Crainic, Dr. V. Voiculescu, Căminul cultural. Indreptar pentru conducătorii la sate (Nichifor Crainic a scris capitolul I), Bucureşti, Fundația Culturală „Principele Carol”, 1924, p. 5.

${ }^{4}$ Franz Shuttack, Comunismul (barbaria secolului XX), în revista „Tiparul Românesc”, 1941, idee preluată de la Francois Mauriac din 1936 care afirmă: „Comunismul, ca şi hitlerismul de altfel, detestă orice viață spirituală care se sustrage concepției sale”, reeditat în „România Literară”, revistă a Uniunii Scriitorilor din România, în articolul François Mauriac şi totalitarismele secolului $X X$, nr. 25, Bucureşti, 28/06/2000, p. 20. 
contemporan, adică transmite învăţătura Cuvântului, pe care Îl centralizează în întreaga ei misiune, într-un gest de dăruire jertfelnică, actualizând întreaga concepție teologică într-o expresie artistică de mare relevanță: „Limbajul, mitul, arta şi religia sunt părți ale acestui univers. Ele sunt firele diferite care țes rețeaua simbolică, țesătura încâlcită a experienței umane. Intregul progres uman, în gândire şi experiență, speculează asupra acestei rețele şi o intăreşte" ".

Preamărindu-1 permanent pe Dumnezeu, într-un pionierat unic în lume şi de neegalat, ortodoxia (chiar cea românească) trece de la credința autentică la faptă, căci ,,credința fără de fapte moartă este"(Iacov 2, 20), fiind nu doar o mamă a credinței care nu te lasă rece, ci o practicantă a credințelor strămoşeşti înglobate şi încreştinate de bogatul tezaur al tradiţiei creştine autentice, delimitarea sau granița dintre intelect şi suflet fiind abandonată, conştientă parcă de faptul că inima are rațiuni pe care rațiunea nu le poate avea, aşa cum susținea Blaise $\mathrm{Pascal}^{6}$, fapt pentru care creştinismul misionar românesc „,nu se reduce la preceptele teologice învățate din Evanghelii şi din cărți, ci e un creştinism manifestat în practicile şi datinile poporului român, care şi-a păstrat autenticitatea lui neslăbită şi nealterată în satele noastre" "7. De aici şi confuzia, la unii critici ai vremurilor, despre panteismul sau neopăgânismul indus, pe care uneori forma artistică a exprimării îl cere,

${ }^{5}$ Ernst Cassirer, Eseu despre om, o introducere în filosofia culturii umane, Bucureşti, Editura Humanitas, 1994, p. 43.

${ }^{6}$ Blaise Pascal, (n. 19 iunie 1623, Clermont-Ferrand, Franța - d. 19 august 1662, Paris) a fost un matematician, fizician şi filosof francez având contribuții în numeroase domenii ale ştiinţei, precum construcţia unor calculatoare mecanice, considerații asupra teoriei probabilităților, studiul fluidelor prin clarificarea conceptelor de presiune şi vid. În urma unei revelații religioase în 1654, Pascal abandonează matematica şi ştiinţele exacte şi îşi dedică viaţa filozofiei şi teologiei.

${ }^{7}$ Pr. Prof. dr. Dumitru Stăniloae, în articolul Poezia creştină a lui Nichifor Crainic, prefața volumului lui Nichifor Crainic, Şoim peste prăpastie. Versuri inedite create în temnițele Aiudului, Bucureşti, Editura Roza Vânturilor, 1990, p. 7. 
dar pe care teologia (inclusiv cea românească) o cenzurează din interior spre exterior, într-o expresie a manifestărilor sale artistice încadrate de spațiul lăuntric fundamental religios al limbajului bisericesc, al formelor fără fond, al teologiei şi al misticii.

Deşi produce frecvent şi cu succes iluzia părăsirii tiparului creştin autentic, prin care auditorul este acaparat spre o comunicare jertfelnică, în esență, ecoul pe care misiunea Bisericii ni-1 transmite este unul atipic, uneori poetic, alteori plin de freamăt dogmatic, iar în afara contextului este pur teologic şi mistic, ambele aspecte fiind tributare spațiului de germinare a creştinismului, ce se caracterizează atât prin conservarea formei arhaice creştine, cât şi prin dinamizarea credinței nealterate $\mathrm{cu}$ credințele străvechi ale popoarelor creştine, într-o țesătură lirică menită a transcende condiția umană după arhetip, deoarece ,orice operă de artă într-o cultură tradițională conduce după anumite urme la contemplarea divinității sau chiar la incorporarea ei", .

Vom vedea pe parcurs că a intra în universul misiunii Bisericii ca vocaţie şi slujire nu atrage după sine stihiile urii de orice natură, căci ura în sine nu este o parte integrantă a misiunii creştine în lume, ci aduce cu sine la lumină o lume patriarhală, bisericească, ortodoxă, luminoasă, caldă, primitoare, jertfelnică, sfântă, optimistă, paradisiacă şi aflată într-o permanentă sărbătoare a sufletului aflat pe drumul primenirii sale; este o lume scăldată de teologia speculativă, dublată de o mistică autohtonă, simţită şi trăită la cel mai înalt nivel al ființei umane. Lumea Bisericii este chiar lumea copilăriei noastre lipsite de griji, este o lume nu a paradisului pierdut, ci a Împărăției lui Dumnezeu dobândite prin har, în care Omul este pus ca încununare a stăpânirii sale peste stihii şi a devenirii lui drept fiu al lui Dumnezeu, pe treapta ce mai înaltă a spiritualizării sale teologice şi mistice.

Contopirea şi unirea oarecum mistică, pe care Biserica o realizează în mădularele sale vii, prin asocierea valorilor ortodoxiei

${ }^{8}$ Adrian Marino, Hermeneutica lui Mircea Eliade, , Cluj-Napoca, Editura Dacia1980, p. 368. 
cu specificul autohton şi naţional al popoarelor, este atât de profundă şi evidentă, încât numeroase critici postmoderne au considerat-o un tot unitar sau ceea ce noi românii afirmăm cu mândrie când spunem că poporul român s-a născut ortodox, în acelaşi timp însă au adus aversiuni din partea unor aşa zişi critici din occident care şi atunci ca şi acum acuză ortodoxia (în speță cea românească) drept răspunzătoare pentru acest fenomen de masă sau mai bine zis de monopol şi chiar dictatură religioasăa, care au făcut cu neputință penetrarea cu uşurinţă a filonului tradiţional privind implementarea ideologiilor occidentale. Putem enumera aici pe Olivier Gillet, care în lucrarea „Religie şi naționalism. Ideologia Bisericii Ortodoxe Române sub regimul comunist"," face afirmații dure la adresa Bisericii Ortodoxe Române, căreia poporul îi acordă cea mai înaltă credibilitate dintre toate Instituţiile Statului Român în toate sondajele $^{10}$ de opinie efectuate după 1989, semn că a fi român înseamnă a fi ortodox, lucru cu greu de înțeles de către un occidental care nu ține seama de rădăcinile orientate religios ale acestui popor şi consideră dreapta credinţă un fenomen antidemocratic. Făcând o mică divagație, observăm astăzi, în societatea aşa zisă modernă, o răsturnare a valorilor clasice cu cele neo-păgâne, într-o lume ce se vrea oarbă, fără țintă, idei şi scop, uşor de controlat, în care majorităţile devin minorităţi majoritare, suferind lezări şi scăderi ființiale, care nu sunt însă luate în seamă de sistemul de stat corupt tocmai de răsturnarea acestor valori.

Ceea ce însă aceşti critici nu au luat în seamă este faptul că specificul românesc, autohton, este ceea ce de fapt s-a îmbinat până la contopire cu ortodoxismul, între acestea existând o unire de idei, care țin de orientarea noastră spre Orient mai mult decât spre Occident, după cum afirma un mare gânditor al teologiei noastre: „Dacă menirea poporului românesc este aceea de a crea o cultură

${ }^{9}$ Olivier Gillet, Religie şi naționalism. Ideologia Bisericii Ortodoxe Române sub regimul comunist, traducere de Mariana Petrişor, Bucureşti, 2000, $313 \mathrm{p}$.

Cf.:http://www.adevarul.ro/actualitate/Romanii-gasesc-salvarea-Biserica Pompieri_0_672533114.html, site accesat la data de 05/11/2012, ora 17:00. 
după chipul şi asemănarea lui, afirmația aceasta implică şi soluția unei orientări. Cine preconizează orientarea spre Occident rosteşte un nonsens. Orientarea cuprinde in sine cuvântul Orient şi înseamnă indreptarea spre Orient, după Orient", ${ }^{\prime \prime}$.

Tocmai de aceea tradiționalismul Bisericii nu reprezintă o închidere în sine ci se dinamizează prin prisma dinamicii ortodoxiei creştine şi a bogatului ei tezaur teologic. De aceea tradiția noastră creştin-ortodoxă constă nu doar în etnicitate ci şi în creştinătate, iar dacă etnicitatea ține în principal de statornicie, creştinătatea vine s-o dinamizeze şi s-o spiritualizeze. Iar asta se vede la tot pasul pe teritoriul țării noastre de la tipărirea primelor cărți de cult şi de literatură ce s-au făcut în sânul Bisericii, monumentele arhitectonice de mare anvergură şi unice în lume, de factură eclesiastică (Voroneț, Mănăstirea Argeşului,etc.), moştenirea lăsată nouă de bravii noştri voievozi şi domnitori, dintre care mulți s-au ridicat la rangul sfințeniei (Brâncoveanu, Ştefan cel Mare şi Sfânt), moştenirea lăsată întregii Biserici Ortodoxe prin danii şi strădanii deosebite (Muntele Athos), prin care a triumfat ortodoxia populară a sufletului românesc împotriva traseismului religios. Acest popor, al cărui specific etnic este precum impresionismul francez, expresionismul german şi orientalismul egiptean, s-a luptat şi cu Ideea lui Platon şi cu numerele lui Pitagora şi cu raționalismul lui Aristotel, triumfând asupra sorții prin credința creştină autohtonă, autentică şi dinamică. El a rămas statornic, apărându-şi tezaurul etnico-religios, fără a duce vreodată războaie de cucerire dar şi dinamic, prin postularea valorilor sale tradiționale. Noi, cei de astăzi, avem multe de învățat din această apologie a trecutului încununată de succes, în lupta înverşunată împotriva răului de orice natură ce nu ne dă pace, ce ne scoate religia din şcoli, ce ne impune căsătoriile homosexuale, ce induc stări conflictuale între cler şi popor, ce ne transformă pe zi ce trece într-o masă biologică uşor de controlat, ca exponenți ai sclavagismului modern, ai urii şi terorii.

${ }^{11}$ Nichifor Crainic, Sensul Tradiției, în revista „Gândirea”, anul IX, nr. 1-2, Bucureşti, 1929, p. 3. 
Misiunea vocațională a Bisericii vine să sublinieze ideea de specific al fiecărui popor asupra căruia nu se pot institui scheme copiate sau împrumutate de la alte popoare, în sânul cărora s-au născut. Ca atare, orice popor are specificul său iar poporul român îşi are propriul specific ce constă din frumoasa împletire dintre etnic, estetic, autohton, tradiție şi creştinismul ortodox al Bisericii noastre, el ființând încă de la început alături de duhul Bisericii Ortodoxe.

Poate că aceste aspecte ar trebui reiterate şi analizate astăzi, când asistăm la o complexă criză de identitate în întreaga lume, provocată de criza de spiritualitate în care omenirea tot mai secularizată se prăbuşeşte. Peste tot în lume observăm o uitare a rădăcinilor din care fiecare neam provine, o uitare şi o negare a credinței, prin aşa zisa succesiune a credinței raționaliste, ştiinţifice. Se pare că omenirea de astăzi vrea să se comporte ca Iuda, nici măcar precum Toma Necredinciosul, care este primul om de ştiință teologică, refuzând categoric supunerea ştiinței adevăratei ştiințe, care este teologia şi mistica, astfel că, probabil, căderea aceasta pe care o induce globalizarea, va fi una profundă, din care este posibil să nu se mai poată ridica. Singura soluție este cea pe care o oferă Biserica prin întoarcerea la rădăcini, prin neuitarea celor ce nu mai sunt, prin tradiția şi etnicul specific fiecărui popor, prin credință şi ascultare întru Cuvânt.

Iată cum Biserica, prin misiunea sa, se dovedeşte o restauratoare a chipului lui Dumnezeu în om, prin întoarcerea la Dumnezeu, la Izvor, la tradiție, la spiritualitate, la teologia practică a misticii creştin-ortodoxe. Sensul Tradiției Ortodoxe al misiunii Bisericii cuprinde toate aceste aspecte într-o magnifică teologhisire a Cuvântului Întrupat, al acelui tablou paradisiac în care se văd împletite esența Bisericii cu tradiţia, cu esteticul, cu etnicul, cu teologia şi mistica ortodoxă, într-o epocală operă de creație creştină oferită întregii lumi. 
Făcând o frumoasă evocare a lui Miguel de Unamuno ${ }^{12}$ privind tradiția şi semnificația acesteia, putem afirma că misiunea Bisericii ca vocaţie şi slujire luminează orizontul destinului creştin în tabloul universal al creației divine, spiritualizându-l în stil bizantin. Ea insistă pe exerciţiul mistic al raţiunii şi inimii deopotrivă, pe concentrarea şi exemplificarea lucrurilor de esență dar care nu sunt vizibile în aparență, după cum adâncul mării nu se vede de la suprafață, pe istoria comună a memoriei creştine, pe transcendență, „pe momentul istoric prezent al intra istoriei" "13 lui Unamuno, ce face din tradiție o prezență ontologică. Forma tradiției creştine, a misiunii Bisericii este una dinamică, dar cu o estetică a formelor în care natura se supune orânduirii omeneşti (codrul este frate $\mathrm{cu}$ românul), ghidate la rându-i de orânduirea divină astfel că geniul artistic al unui popor, şi în speță cel român, trebuie să fie după chipul şi asemănarea lui, ca într-o poezie muzicală ghidată de mecanica divină a formelor ce se regăseşte la noi în spiritualitatea şi spiritualismul Bisericii noastre ortodoxe: ,Această concepție formală se suprapune minunat simțului artistic al poporului românesc ${ }^{, 14}$.

Aşezând sau centrând credința creştin ortodoxă pe tradiție, Biserica reîncreştinează un popor deja creştin, în sensul promovării teologiei şi misticii la nivelul ființei umane în totalitate, a cărei centralitate o dă Însuşi Hristos Omul şi Dumnezeu. Prin aceasta creştinismul misionar spiritualizează existenţa unui întreg popor şi face din credinţă, tradiție, ortodoxie, teologie şi mistică un act istoric, readucându-L pe Dumnezeu în creație, iar pe om repunându-1 stăpânul deplin al acesteia, ca într-o slujire monumentală prin care acesta e menit să se înalțe la Creatorul său şi prin sine, întreaga lui stăpânire, ca un imn de slavă eclesiologică din Ambigua Sfântului Maxim Mărturisitorul (Confesorul).

${ }^{12}$ Miguel de Unamuno (n. 29 septembrie 1864, în Bilbao, d. 31 decembrie, în Salamanca) a fost un prozator spaniol, filozof, profesor, eseist, poet şi dramaturg.

${ }^{13}$ Nichifor Crainic, Sensul Tradiției...,p. 5.

${ }^{14}$ Ibidem, p. 9. 
Spiritualitatea, vocația şi slujirea pe care o propune Biserica este una nepieritoarea, înflăcărată, profundă, liberă şi plină de duh, este autentică, autohtonă, tradițională, arhaică, teologică, ființială şi dinamică, plină de originalitatea ce oferă cu adevărat stabilitatea şi continuitatea creştin-ortodoxă. Prin aceasta se asigură nu doar drumul românilor spre Europa unită a zilelor noastre, pe care Biserica cea una doreşte să o îmbrăţişeze cu ardoare, dar se asigură şi continuitatea noastră ca popor specific şi dinamic în tabloul multicolor al culturilor europene în care ne-am născut şi în care ființăm. Personal, mi-aş fi dorit ca misiunea Bisericii să-şi găsească astăzi, în vreme de criză spirituală, ideologică, economică şi ființială, o promovare pe deplin meritată şi chiar o implementare, ea fiind cel dintâi martor care a dovedit eficacitatea şi perenitatea unui astfel de demers.

Pornind de la filonul tradiției creştine, misiunea Bisericii defineşte filonul tradiției popoarelor şi face acea minunată trecere de la cultura de consum, împrumutată, la cultura şi creația autentică a geniului național, care au făcut cu putința rezistența creştină de-a lungul vremurilor prin cultura tradiţională şi creştină, punând pe firmament spre exemplificare, geniile popoarelor creştine ce s-au făcut cunoscute în plan internațional tocmai prin statornicia şi dinamica tradiției cu adânci rădăcini creştine: „Cultura e legată de cult, ea se dezvoltă pornind din cultul religios, ea e rezultatul diferențierii şi a extensiunii cultului. Cugetarea filosofică, cunoaşterea ştiințifică, arhitectura, sculptura, pictura, muzica, poezia şi morala-totul e cuprins în cultul Bisericii organic şi integral, sub o formă incă nediferențiată. Cultura e legată de cultul strămoşilor şi de tradiție. Ea e plină de un simbolism sacru, ea poartă în sine semnele şi imaginile unei realități de ordin spiritual ${ }^{\prime \prime 15}$.

Exemplificând acest aspect, creştinismul scoate spre cercetare cultura şi arta creştină, prin care a ființat Biserica dea lungul

${ }^{15}$ Ibidem, p. 8. 
mileniilor şi odată cu aceasta s-a păstrat intactă şi nealterată credința, limba şi ființa religiei creştine.

Vitalitatea şi rezistența creştinismului s-au împlinit prin vocația misiunii şi misiunea slujirii Bisericii în lume, care s-a suprapus peste cultura popoarelor, ce a prins rădăcini adânci creştine în toate aspectele vieții în cea mai intimă unire spirituală, în centrul căreia a tronat dintotdeauna Biserica lui Hristos Cuvântul. În sistemul său teologic şi mistic, Biserica îl aşează în centru pe Hristos, Cuvântul lui Dumnezeu, propovăduit de Biserica Sa. Cosmologia Bisericii este una misionară, în care tronează Rațiunea lui Dumnezeu şi în care se manifestă Duhul de viaţă dătător. Omul ocupă locul său central în creație după cum Hristos este centralitatea teologiei şi misticii sale autentic ortodoxe. Originalitatea misionară vine pe fondul promovării valorilor creştin-ortodoxe la un nivel academic, autentic, dinamic, prin care teologia şi mistica devin pârghii şi unelte nu doar ale harului ci şi ale unui sistem teologic şi mistic de profunzime, care au făcut cu putință punerea în lumină a unui tezaur păstrat în conservare.

În lumina acestor observații ne putem mândri cu o originalitate creştină de excepție, unică în lume, din păcate nedescoperită şi nepromovată la un nivel la care să poată accede întreaga lume din care facem parte. Aşa cum Biserica a redescoperit teologia şi mistica ascunse sub obroc precum înțelepciunea fecioarelor, tot aşa suntem noi datori a redescoperi valorile noastre naţionale, suprapuse cu cele creştin-ortodoxe, pe care să le promovăm în lume fără să ne ruşinăm de impozantul tezaur cultural misionar de care dispunem dar pe care nu-1 propunem spre cercetare. Misiunea noastră este una capitală astăzi când asistăm cu lâncedă nepăsare la crimele împotriva culturii noastre naționale. Este revoltător cum anumiţi factori de decizie ne dezrădăcinează sistematic de aceste valori dar care sper, spre a lor disperare, nu vor putea nici de această dată să scindeze unitatea ființei naționale, clădite pe unitatea credinței creștin-ortodoxe. Acest popor are tăria să suspine :, cine va răbda până la sfârşit acela se va 
mântui” "16 dar are şi dezinvoltura necesară împlinirii misiunii sale europene, după cum întrevedea un mare filosof (Hermann Alexander Graf Keyserling) care afirmă că: „dacă românii au o misiune europeană de îndeplinit, această misiune stă în «a redeştepta la o viață nouă bizantinismul》». Şi fireşte, acest popor şi această țară pot să aibă un mare viitor" $"$.

Sistemul misionar al Bisericii creştine ne propune o sociologie a trăirii experimentale, fundamentată pe viziunea autohtonă, tradițională şi cu aspect de comunitate evanghelică primară, în care sentimentul revederii hristice devine nostalgia paradisului pierdut iar umanitatea îşi clădeşte structura emoțională şi unirea mistică într-o structură eclesiastică a statului etnocratic, în care Cuvântul lui Dumnezeu, Hristos-Omul, este centrul spiritului național, tradițional şi creştin ortodox.

Toleranța creştină merge până la stadiul comportamentului deviat simbolizat în Sfânta Scriptură prin persoana vameşului, judecata faptelor fiind apanajul Bisericii creştine autentice, ce face dovada autorității divine ca trup tainic al Logosului. Ea devine un imbold al speculaţiei sale teologice şi mistice, precum şi un îndreptar politic de apărare a ființei naționale şi a credinței ortodoxe. Iată una din definițiile misiunii Bisericii astăzi.

Creştinismul ortodox este trăire mistică, speculativă, orientală iar dacă facem referire la creştinismul românesc autentic putem spune despre poporul român că este un popor al folclorului, al basmelor, al tradițiilor, al vieții experimentale, al teologiei şi al misticii. Ne naştem cu Făt-Frumos dar şi cu Pruncul Iisus, copilărim cu Prâslea cel Voinic şi merele de aur dar şi cu Magii de la Răsărit, ne maturizăm cu exemplul bravilor noştri voievozi dar şi cu martiriul sfinţilor, trecem dincolo cu povestea bradului dar şi cu împărtăşirea

${ }^{16}$ Biblia sau Sfânta Scriptură, Matei cap. 10, v. 22, tipărită sub îndrumarea şi cu purtarea de grijă a Preafericitului Părinte Teoctist cu aprobarea Sfântului Sinod, Editura Institutului Biblic şi de Misiune al Bisericii Ortodoxe Române, Bucureşti, 2006, p. 1108.

${ }^{17}$ Nichifor Crainic, Sensul Tradiției, în revista "Gândirea", anul IX, nr. 1-2, Bucureşti, 1929, p. 10. 
harului Duhului Sfânt. Iată o altă definiție a misiunii Bisericii ce se încadrează în specificul creştin românesc.

Textul sacru devine, în misiunea Bisericii astăzi, text al cuvântului teologic tipizat, în sensul că normativ este pentru acesta Sfânta Scriptură şi Sfânta Tradiţie precum şi scrierile Sfinților Părinți, teologhisirea religioasă ${ }^{18}$ a misiunii Bisericii fiind autentică. Ca slujitori ai sfintelor altare ale Bisericii Ortodoxe Române, nu putem gândi la misiunea creştină în lume fără a cunoaşte şi a aprofunda „Invățăturile lui Neagoe Basarab către fiul său Teodosie”, „Psaltirea” diaconului Coresi de la 1577 (Braşov), "Cartea românească de invățătură" a mitropolitului Varlaam de la 1643, „Psaltirea in versuri” a mitropolitului Dosoftei de la 1673 de la Uniev, lucrări în care se distinge cu precădere textul religios sacru împletit cu legendele religioase de natură apocrifă şi care au putut genera mai târziu primele apariții ale Sfintei Scripturi în limba română, adică primul îndreptar al misiunii Bisericii în lume. Pe acest fond îşi fundamentează Trupul mistic al lui Hristos teologia şi mistica folosind atât invocatio Christi cât şi mysterium tremendum al lui Rudolf Otto $^{19}$, amplificând vibrația religioasă a propriului ego creştin, pe care o îmbină cu specificul şi mentalitatea societăţii vremurilor în care trăim, o sinteză şi o simbioză în care misiunea Bisericii se întâlneşte cu textul scripturistic, cu meditaţia ascetică, cu tradiția, cu naţionalismul şi cu patosul misiunii Bisericii: „Biserica noastră, acoperământ ocrotitor al tuturor artelor, le-a folosit pe toate de la început pentru a plasticiza mai puternic adevărurile

${ }^{18}$ Edgar Papu, Evoluția şi Formele genului liric, în care afirmă: "Cuvântul revelat are aceeaşi funcție ca şi cuvântul folosit în practicile magice, nemaifiind denumirea unei noțiuni ci o realitate de sine stătătoare care are o dinamică proprie cu o funcțiune fascinatorie, menită să introducă în noi, pe calea auzului, o voință şi o obsesie străină, care să înlocuiască pentru moment propria noastră voință. Repetiția cuvântului este aceea care duce la desprinderea de îmțelesul său inițial şi la funcționarea lui autonomă”, Editura Tineretului, București, 1968, p. 22.

${ }^{19}$ Rudolf Otto, Sacrul, Editura Dacia, Cluj-Napoca, 2002, p. 12. 
spirituale ale credinței. In slava lui Dumnezeu, poezia ocupă cea mai largă parte" $" 20$.

Este clar că în epoca noastră învățătura creştin-ortodoxă nu este încă pe deplin cunoscută. Şi acum, ca şi în trecutul Istoriei Universale a Bisericii, sunt voci perfide la adresa Bisericii şi a duhului acesteia, pe care le vedem manifestându-se chiar şi în țara noastră, excepție făcând spiritele luminate ale Academiei Române, care sunt conştiente de masiva influență a creştinismului în istoria poporului român şi a culturii sale. Acest lucru era vizibil încă din perioada interbelică, când România eliberată de influențele imperiilor destrămate, tindea spre o uniune europeană, însă un pic forțată, dând uitării cu prea mare uşurință tuturor valorilor care au contribuit la modelarea spirituală şi socială a acestui popor.

În fața unor atitudini extremiste nu te poți ridica decât ferm şi acest lucru îl face şi Biserica prin misiunea sa, care realizează o analiză psihologică profundă în ființa umanității, scoțând în evidență deviațiile spirituale şi căile greşite spre care se îndreaptă astăzi omenirea, aflată nu doar într-o colosală criză de spiritualitate, ci şi într-o criză economică, socială şi politică ce aduc omenirea în pragul unui posibil război mondial.

Societatea de astăzi este şovăitoare în credință sau ceea ce Scriptura numeşte cu termenul de „căldicei” (Apocalipsa 3, 15-16), motiv pentru care şi zbuciumul său este pe măsură, punându-l pe omul libertin slujind răului şi nu liber slujind lui Dumnezeu. Este un cerc vicios, precum este păcatul împotriva Duhului Sfânt în care criza spirituală duce la criza morală şi socială a omului ce se depărtează tot mai mult de Dumnezeu.

Biserica se dovedeşte a fi nu doar un foarte fin psiholog, ci şi o foarte bună cunoscătoare a acestor aspecte ce țin de misiunea şi slujirea ei, motiv pentru care în mod profetic atrage atenția societăţii umane asupra pericolului înstrăinării de propriile rădăcini. Este de

${ }^{20}$ Nichifor Crainic, Manuscrise arestate, în revista „Manuscriptum” editată de Ministerul Culturii şi Muzeul Literaturii Române, fondator D. PanaitescuPerpessicius, nr. special (100), anul XXVI, nr. 1-4, 1995, p. 230. 
ajuns să privim astăzi la criza prin care nu doar lumea trece ci prin care românii ca popor trec. Asistăm din nou la inculturalitate, multiculturalitate sau la o cultură de import, lovinescieni şi cioculescieni existând şi astăzi (mă refer strict la atitudinea lor față de ortodoxie şi nu la evidenta valoare a creațiilor lor culturale) în cultura românească unde, din păcate, lipsesc cu desăvârşire apologeți de talia unui Nichifor Crainic, a unui Nae Ionescu sau Dumitru Stăniloae. Negarea propriilor rădăcini este ca şi negarea de propria mamă şi statutul de ,,avorton" ${ }^{21}$ sau blestem din care cu greu cineva se mai poate ridica, de aceea misiunea Bisericii din zilele noastre face apel la autoritatea dată de Hristos Însuşi Bisericii creştine, în încercarea sa disperată de a salva ființa poporului din care ea însăşi face parte.

Apologia misionară la care este chemată astăzi Biserica este una de excepție, ce ține de ființa ei, deoarece propovăduirea Evangheliei lui Hristos la toate neamurile şi chemarea la „reconciliere prin pocăință şi botez" ${ }^{22}$ este o vocație eclezială apostolică. Biserica este chemată mai mult ca oricând să descopere semnele cuvântului lui Dumnezeu; ,formarea unei comunități autentice la nivel local, care să includă pe toți, fără nici o deosebire de sex, vârstă sau profesie şi care să pună accentul pe relațiile umane personale, redescoperirea unei comunități tămăduitoare de susținere şi de iubire activă." 23

${ }^{21}$ cf. Academia Română, Dicționarul explicativ al limbii române (ediția a II-a revăzută şi adăugită), al Institutului de Lingvistică "Iorgu Iordan", Bucureşti, Editura Univers Enciclopedic Gold, 2012. Avortón, avortoni, s. m. Ființă născută înainte de termen; $p$. ext. om degenerat, cu mari deficiențe. Fig. Operă (literară, artistică) ratată. - Din fr. avorton. cf. Academia Română, Dicționarul explicativ al limbii române (ediția a II-a revăzută şi adăugită), al Institutului de Lingvistică "Iorgu Iordan", Bucureşti, Editura Univers Enciclopedic Gold, 2012.

${ }^{22}$ Bria, Pr. Prof. Dr. Ioan, Dicționar de teologie ortodoxă, Bucureşti, Editura Institutului Biblic şi de Misiune a Bisericii Ortodoxe Române, 1994, p. 254 .

Dr. Nifon Mihăiță, Misiologie Creştină, Editura ASA, Editura Universității Valahia din Târgovişte, 2001, p.36. 
Făcând aceasta, Biserica se substituie tuturor nevoilor omeneşti pe care le înduhovniceşte în spaţiu şi timp, făcând din misiunea sa misiunea noastră a tuturor celor înduhovniciţi, activând desăvârşit ca mădulare vii în trupul lui Hristos. Este un proces cu adânci implicații sociale şi totodată un îndemn la Unitatea Treimică, ca reflex al unirii Treimice, spre unitatea neamului omenesc, căci nu va mai fi „,nici elin, nici iudeu; nu mai este nici rob, nici liber; nu mai este parte bărbătească şi parte femeiască, pentru că voi toți una sunteți în Hristos Iisus" (Galateni 3, 28).

Creştinii, transformaţi de Cuvântul pe care 1-au auzit şi cu care s-au împărtăşit la Liturghie, trebuie „să trăiască semnele profetice ale Impărăției ce vine." 24 . Această misiune a Bisericii celei Una nu este doar una singulară, ci este o sumă de manifestări pe care credinciosul le săvârşeşte personal, dar şi în agape, înmulțind cu prisosinţă talantul ce ni s-a dat începând cu taina Botezului, întărit prin Mirungere şi confirmat prin Euharistie. De aceea, rolul laicilor în misiune este fundamental: ei „trebuie să dea mărturie de puterea şi înțelepciunea lui Dumnezeu, de puterea şi lucrarea Duhului",25.

Tocmai de aceea, asistând la atrocitățile lumii moderne sau aşa-zise moderne, Biserica prin slujitorii şi credincioşii săi pune la loc de cinste şi sintetizează moraliceşte drepturile dar şi îndatoririle persoanei umane, şi prin aceasta a întregii umanităţi. Biserica este aşadar eliberatoarea nu doar din robia păcatului, ci şi din robia acestei lumi secularizate, lipsită de dinamicitate şi eficacitate, privată de nemuritoarele Legi divine ale creştinismului. Şi vedem la tot pasul aspecte care ne îngrijorează şi ne obligă în a lua o atitudine fermă, păstrând cu sfințenie demnitatea persoanei umane, în care este imprimat chipul lui Dumnezeu, ce trebuie restaurant prin har. Sunt veşti de războaie şi se comandă războaie, sunt vremuri de criză şi se provoacă criză, sunt vremuri de amăgire şi se provoacă amăgire, sunt vremuri de rătăcire şi se inoculează rătăcire. Omul este adus pe

${ }^{24}$ Ibidem, p.73

${ }^{25}$ Coman, Pr. Prof. Dr. Constantin, Biblia în Biserică, Bucureşti, Editura Bizantină, 1997, p.165. 
culmile disperării, ideea de atrocitate este preluată apocaliptic astfel încât, întregul eşec spiritual al lumii moderne să fie pus pe seama divinității şi nu a neascultării de care dă dovadă cu încăpățânare această lume. Suntem intenționat dirijați spre credințe oculte astfel încât să dăm crezare ici şi colo unor învăţături ce nu au nici pe departe legătura cu Tradiția şi Viaţa Bisericii. În această rătăcire, care poate fi cea de pe urmă, ființa umană, în complexitatea ei este mințită şi arvunită păcatului, semn clar al lepădării de credință, ce ne va distrage atenția de la adevăratele valori spiritual, lăsându-ne nepregătiți asemeni fecioarelor neînțelepte în fața „Furului”. Predicarea Evangheliei este misiunea principală a Bisericii lui Hristos şi ,aceasta are prioritate în fața oricărei alte slujiri" ${ }^{26}$

Dezbrăcaţi de harul divin, privaţi de deplina noastră libertate, riscăm să rătăcim pe drumuri neştiute, departe de Biserică, plutind pe valurile vieții şi naufragiind în diverse păcate şi vicii din care cu greu ne mai putem salva, prin faptul că noi singuri ne privăm de dialogul continuu cu Dumnezeu, în Biserică, la rugăciune. Numai acolo, în Biserica Mamă, ne putem înduhovnici, luând „pavăza credinței, cu care veți putea să stingeți toate săgețile cele arzătoare ale vicleanului. Luați şi coiful mântuirii şi sabia Duhului, care este cuvântul lui Dumnezeu”. (Efeseni 6, 16-17)

Creştinismul de azi trebuie să arate că atenția acordată vieții veşnice aduce cu sine şi o transformare a acestei lumi. A fi ucenic al Domnului înseamnă să-ți iubeşti aproapele, să-i împărtăşeşti grijile şi sa-ți manifeşti dragostea prin lucruri concrete. Prin urmare, noi trebuie să proclamăm cu tărie că misiunea Evangheliei nu este aceea de a transforma pământul într-un paradis prosper, pentru că țelul final este dobândirea vieții veşnice. „Noi trebuie să trăim în Hristos, legătura cu Tatăl sub lucrarea Duhului Sfânt. Ne vom simți atunci ca unii asupra cărora se odihneşte Duhul Sfânt, aşa cum se odihneşte şi asupra Fiului. Ştim că primim mereu darul Duhului Sfânt prin rugăciunile Bisericii. Prin darul Duhului Sfânt lucrează în Biserica

${ }^{26}$ Ibidem, p. 27. 
şi în noi energiile Duhului Sfânt, energiile necreate aşa cum le-au numit unii Sfinții Părinți ai Bisericii “27.

Biserica are „misiunea” de a vesti lumii Împărăția lui Dumnezeu. Fiindcă Bisericii i s-a dat prezența Duhului Sfânt ca garanţie, ea este în mijlocul nostru, ,eshatonul” este deja accesibil lumii. Prin urmare, Biserica este comunitatea eshatologică, popor pelerin, care trăieşte în aşteptarea fierbinte a reîntoarcerii Domnului, pe Care Îl mărturiseşte în faţa lumii. Misiunea ține de însăşi natura Bisericii, în orice condiții ar trăi ea, iar fără misiune nu poate exista Biserica, fiindcă Biserica duce mai departe lucrarea de mântuire a lumii, descoperită şi înfãptuita de Mântuitorul Iisus Hristos.

Din acest punct de vedere, afirmarea curajoasă a misiunii Bisericii în lumea secularizată a zilelor noastre nu poate fi decât îmbucurătoare, ținând totdeauna cont de aspectul dinamic al tradiției, etnicului, naţionalului şi creştinismului de pretutindeni. Nu trebuie să trecem cu vederea ideile misiunii creştine deschizătoare de drumuri în teologia modernă, cum ar fi: misiunea Bisericii în societatea postmodernă, raportul Bisericii creştin-ortodoxe cu celelalte confesiuni şi culte, aspectul ecumenic al dialogului inter-religios, aspecte privind teologia culturii, sociologia şi psihologia religiilor, diplomația eclesiastică, teologie şi cultură, teologie şi artă, teologie şi medicină, teologie şi societate, raportul dintre teologie, spiritualitate, mistică şi duhovnicie, literatura eclesiastică, cultura eclesiastică, poezia religioasă, arta creştină. Toate aceste aspecte ale misiunii Bisericii, ce țin de vocația şi slujirea ei, lasă loc unor cercetări ulterioare la care cu siguranță trebuie să ne angajăm cu toții, într-o apologie coerentă a tuturor fraților creştini de pretutindeni, căci doar îndrăznind şi sădind pretutindeni în lume Cuvântul lui Dumnezeu putem birui lumea, în sensul hristic al cuvântului.

Hristos a Înviat!

${ }^{27}$ M.Costa de Beauregard, Dumitru Stăniloae, Mica dogmatică vorbită, Sibiu, Edit. Deisis, 1995, p. 31. 


\section{Bibliografie}

1. Beauregard, M. A. Costa de, Stăniloae, Dumitru, Mica dogmatică vorbită, Sibiu, Editura Deisis, 1995.

2. Bria, Ion, Dicționar de Teologie Ortodoxă, Bucureşti, Editura Institutului Biblic si de Misiune a Bisericii Ortodoxe Române, 1994.

3. Clément, Olivier, Dumitru Stăniloae sau Paradoxul teologiei, Bucureşti, Editura Anastasia, 2003.

4. Coman, Constantin, Biblia în Biserică, Bucureşti, Editura Bizantină, 1997.

5. Evdochimov, Paul, Iubirea nebună a lui Dumnezeu, Bucureşti, Editura Anastasia, 1993.

6. Léon-Dufour, Xavier, Vocabular de Teologie Biblică, Bucureşti, Editura EARCB, 2001.

7. Marcu, Grigore C., Omul cel Nou în concepția antropologică a Sfântului Apostol Pavel, în „Studii Teologice”, nr. 7-8, 1951.

8. Meyendorff, John, Teologia Bizantină, Bucureşti, Editura Institutului Biblic şi de Misiune a Bisericii Ortodoxe Române, 1996.

9. Mihăiță, Nifon, Misiologie Creştină, Târgovişte, Editura ASA, Editura Universității Valahia din Târgovişte, 2001.

10. Moldovan, Ilie, Familia şi Viața la începutul unui nou mileniu creştin, Bucureşti, Editura Institutului Biblic şi de Misiune a Bisericii Ortodoxe Române, 2001.

11. Popescu, Dumitru, Hristos, Biserică, Societate, Bucureşti, Editura Institutului Biblic şi de Misiune a Bisericii Ortodoxe Române, 1998.

12. Idem, Teologie şi cultură, Bucureşti, Editura Institutului Biblic şi de Misiune a Bisericii Ortodoxe Române, 1993. 